3. Права в'язнів (матеріали вебінару ХПГ 16.06.2021) URL: http://khpg.org/1608809215

4. Романов М.В. Міжнародний досвід забезпечення права на медичну допомогу засудженим. Право і суспільство. 2019. Випуск 4. С. 261-266.

5. Доповідь Уповноваженого Верховної Ради України з прав людини щодо імплементації в Україні Конвенції ООН проти катувань та інших жорстоких, нелюдських або таких, що принижують гідність, видів поводження і покарання за 2020 рік. Ст. 18. URL: https://tbinternet.ohchr.org/Treaties/CAT/Shared\%20Documents/UKR/ INT_CAT_INP_UKR_42469_O.PDF (дата звернення: 18.03.2021).

\title{
DOI https://doi.org/10.30525/978-9934-26-116-9-32
}

\section{СУЧАСНИЙ СТАН КРИМІНОЛОГІЇ В УКРАЇНІ}

\author{
Коростельова Л. А.
}

ад 'юнкт Луганського державного університету внутрішніх справ імені Е. О. Дідоренка м. Сєвєродонеиьк, Україна

Життя людського суспільства 3 давніх давен характеризувалося не тільки (i не стільки) злагодою і порозумінням, а більшою мірою присутністю в ньому суперечностей і конфліктів. На грунті таких суперечностей i конфліктів і утворився особливий вид соціальної діяльності - злочинна діяльність. По мірі інтернаціоналізації життя, виникнення проблем, притаманних міжнародному суспільству як соціальній мега цілісності, стали формуватися міжнародні механізми злочинності. Злочинність стала предметом уваги правових наук. Передусім, це кримінальне, кримінально-процесуальне, кримінально-виконавче право - вони визначили порядок боротьби із злочинами. Криміналістична наука, медицина, юридична психологія і інші залучили до боротьби із злочинністю наукові засоби і методи. Втім жодна із згаданих чи інших наук не в змозі охопити проблему злочинності у цілому. Але вони створили умови для виникнення спеціальної науки кримінології [1, с. 21].

Сучасний стан розвитку кримінології в Україні потребує модернізації, оскільки існує проблематика не визначеності кримінології як 
науки. Це, пов'язано з тим, що питання про поняття та природу кримінології й надалі залишається дискусійним не лише у вітчизняній, а й у зарубіжній кримінології [2, с. 12].

Питання визначеності кримінології як науки приділи увагу такі вчені як Г.А. Аванесов, Ю.М.Антонян, А.І.Глінський, А.П. Закалюк, А.Ф. Зелінський, А.І. Долгова, І.М. Даншин, В.В. Голіна, Б.М. Головкін, О.В. Павленко,С.Л. Сибіряков та інші.

У сучасному розумінні кримінологія- це наука про закономірності виникнення, функціонування, розвитку злочинності і боротьби з нею. Наведене визначення лаконічно відбиває сутність кримінології як науки про злочинність, форми, види і методи боротьби з нею [3, с. 11].

Водночас у літературних джерелах $є$ інші визначення щодо поняття кримінології.

Так, наприклад Г.А. Аванесов визначає, що кримінологія-відносно самостійна система знань, яка в той же час $є$ елементом системи науки взагалі, і особлива форма діяльності людей, яка об'єднує вчених i наукові установи, призначені для вивчення злочинності як соціальноправового явища, iii закономірностей, характерних для минулого, сучасного та майбутнього, причин злочинності, особи злочинця, для розробки заходів попередження злочинності та профілактики злочинів, 3 метою вдосконалення теорії і практики в боротьбі зі злочинністю. Слід звернути увагу на визначення поняття кримінологія, яке висвітлює відомий український кримінолог А.Ф. Зелінський, під кримінологіє розуміється наука про злочинність і злочин, їх причини і умови, які їм сприяють, особу злочинця та його жертву, а також пов'язані зі злочинністю явища відхиляючої антисоціальної поведінки, шляхах і засобах попередження злочинності. В.М.Кудрявцев, В.С. Емінов зазначають, що кримінологія - загальнотеоретична наука про злочинність, iii причини і умови, що їй супутні, особи тих, хто вчинює злочини, а також методах контролю за злочинністю та боротьби 3 нею (включаючи до поняття боротьби зі злочинністю та ії попередження). С.Л. Сибіряков, під кримінологією розуміє науку про пізнання злочинності [4, с. 13-15].

Варто звернути увагу, на думку таких вчених О.В. Баляби, Е.В. Віленської, Е.О. Дідоренка, Б.Г.Розовського, які визначили поняття кримінології в монографії «Криминологія: приглашение к дискуссии», і зазначили, що кримінологія - самостійна наука, зі своїм предметом дослідження, яка використовує досягнення інших наук, кримінологія формує свій понятійний апарат, комплексний метод дослідження, iii дослідження орієнтовані та отримання кінцевих 
результатів, які мають практичну реалізацію законодавчу і правоохоронну діяльність [5, с. 12].

Отже, проаналізувавши думки різних вчених стосовно поняття кримінології, можна сказати, що різні підходи до поняття кримінології визначають неоднозначність місця кримінології в системі наук України.

Зокрема, англосаксонська система кримінології вважає ії галуззю соціології, тому викладають її в соціологічних, а не в юридичних вузах. В італійській науці акцент робиться на біологічному аспекті кримінології, у французькій - на клінічному, пов'язаному з психологічними та психіатричними аномаліями. У Німеччині конкурують два напрями біологічний і соціологічний, з домінуванням останнього [2, с. 12].

В Україні розглядають кримінологію як юридичну науку, але існує низка науковців які відносять кримінологію до соціології. Можна виділити дві групи кримінологів-юристів, які порушують проблемне питання.

Перша група відстоює «юридично чисту» кримінологію. Так, I.I. Карпець, А.І. Долгова, які читко відрізняють кримінологію від соціології.

Також вже згадувані вчені О.В. Баляба, Е.В. Віленська, Е.О. Дідоренко, Б.Г. Розовський, які чітко визначили різницю між кримінологією та соціологією, зазначивши, що кримінологія вивчає злочинність, якості дефекту системи правового регулювання суспільних відносин, розробляс правові заходи впливу на причини злочинності, на особу потенційного злочинця. I в цьому є специфічна різниця між соціологією [5, с. 19].

Друга група критично оцінює становище в сучасній кримінології, i визначає, що кримінологія повинна перебороти нормативістську парадигму і більше орієнтуватися на факти, на соціологічні та психологічні дослідження. Таку думку відстоював український кримінолог А.Ф. Зелінський.

Ю.Д. Блувштейн і А.В.Добринін, дійшли висновку, що в кримінології існують дві парадигми: нормативістьська і соціологічна. Друга парадигма саме й втілюється у соціології злочинності, яка виступає як наука власне індуктивної природи, а от нормативістьська кримінологія- наука дедуктивна [6, с. 23].

B.I. Поклад, зазначає, що по-перше, необхідно визнати наявність і рівноправність всередині кримінології трьох основних парадигм: кримінально-правовий, соціологічної і психологічної. По-друге, слід виділити кримінологію зі спеціальності 12.00.08 («кримінальне право і кримінологія; кримінально-виконавче право») і надати самостійну 132 
позицію в «ваківському» реєстрі наук. I, нарешті, по-третє, дозволити проводити дисертаційні дослідження і захищати їх кримінологам з базовою юридичною, соціологічною і психологічною освітою [7].

Проведений аналіз показує, що сучасна вітчизняна кримінологія, має ознаки кризи. Це, зокрема, виявляється у тому, що поширення в ній набув так званий еклектичний позитивізм, який має вигляд «теорії факторів». Зазначена теорія не розрізняе причини злочинності й умови, що ій сприяють. Іншими словами, має місце у кримінології стан, за якого дослідники «за деревами не бачать лісу». Ця позитивістська доктрина призводить до волюнтаризму й утопізму у протидії злочинності на практиці, що, зокрема, проявляється у неадекватному використанні засобів кримінальної юстиції й ігноруванні нерепресивних засобів протидії злочинності [6, с. 204].

Отже, підсумовуючи вище зазначене можна зробити висновок, «криза», в якій перебуває кримінологія, потребує більшого уточнення поняття, визначення предмету, і висвітлення питань методології i методики кримінологічних досліджень.

\section{Література:}

1. Антипенко В.Ф. Міжнародна кримінологія. Досвід дослідження тероризму: монографія. Київ: Фенікс, 2011. 352 с.

2. Богатирьов I. Г. Кримінологія : підручник. Київ: Дакор, 2019. $352 \mathrm{c}$.

3. Головкін Б.М. Кримінологія: підручник. Харків: Право, 2020. 384 c.

4. Денисов С.Ф., Денисова Т.А., Кулик С.Г., Шеремет О.С. Кримінологія. Загальна частина. Альбом схем: навч.посіб. Чернігів: Десна, 2015. 658 c.

5. Баляба А.В., Виленская С.В., Дидоренко С.А., Розовский Б.Г. Криминология: приглашение к дисскусии: монография. Луганск: РИО ЛИВД, 2000. 318 с.

6. Костенко О.М. Сучасні тенденції розвитку кримінальної юстиції та кримінології в Україні. Правова держава. 2014. Вип. 25. С. 204-225.

7. Поклад В.И. К вопросу о предметном статусе криминологии в Украине URL: https://dspace.lduvs.edu.ua/bitstream/123456789/488/1/ Статья\%20-\%20Одесса.pdf (дата звернення: 26.06.2021). 